\title{
Balkanologie
}

Balkanologie Revue d'études pluridisciplinaires

Vol. XII, $n^{\circ} 1$ | 2010

Volume XII Numéro 1

\section{Homeland in the fiction and written narratives of ethnic Greeks from the former Soviet Union (FSU) in Greece}

Kira Kaurinkoski

\author{
(2) OpenEdition \\ Journals \\ Electronic version \\ URL: http://journals.openedition.org/balkanologie/2141 \\ DOI: 10.4000/balkanologie.2141 \\ ISSN: 1965-0582 \\ Publisher \\ Association française d'études sur les Balkans (Afebalk)
}

\section{Electronic reference}

Kira Kaurinkoski, «Homeland in the fiction and written narratives of ethnic Greeks from the former Soviet Union (FSU) in Greece », Balkanologie [Online], Vol. XII, n 1 | 2010, Online since 31 March 2010, connection on 17 December 2020. URL : http://journals.openedition.org/balkanologie/2141 ; DOI : https://doi.org/10.4000/balkanologie.2141

\section{This text was automatically generated on 17 December 2020.}

(c) Tous droits réservés 


\title{
Homeland in the fiction and written narratives of ethnic Greeks from the former Soviet Union (FSU) in Greece
}

\author{
Kira Kaurinkoski
}

\section{AUTHOR'S NOTE}

This paper is a revised version of a conference presentation made at the session "Homeland and Diaspora : Imagination and Reality" convened by Maria Yelenevskaya (Technion-Israel Institute of Technology) and Larisa Fialkova (University of Haifa) at the $9^{\text {th }}$ SIEF Conference at the University of Ulster, Northern Ireland, 16-20 June 2008.

I wish to express my gratitude to the French School of Athens whose grant enabled me to take part in the $9^{\text {th }}$ conference of SIEF at the University of Ulster, Northern Ireland in June 2008. My gratitude also goes to Katerina Seraïdari, Martin Baldwin-Edwards and to two anonymous readers from Balkanologie for their critical comments and suggestions on earlier drafts of this paper. Finally, special thanks to Martin Baldwin-Edwards who took the time to correct my English.

1 The aim of this paper is to discuss fiction written by the ethnic Greeks who have arrived in Greece from the FSU since perestroika. In the first place, I will address the way that the concrete experiences of migration and settlement are discussed in the fictions concerned. Then I will look at questions related to ascription and selfascription of identities and the politics of difference. Finally, I will discuss the representations of home(s) and homeland(s).

In the mid-1980s with the beginning of perestroika in the Soviet Union an increasing number of people (including ethnic Greeks) started writing short stories, novels and autobiographical work where they reflected on their history, lives and identities ${ }^{1}$. In Greece, the emergence of fiction written by ethnic Greeks from the former Soviet Union (FSU) is a recent phenomenon ${ }^{2}$. The first novels and short stories were published 
in the 1990s in weekly Athens-based Russian language newspapers which started appearing at that time ${ }^{3}$. They are migration stories which discuss the fate of ethnic Greek and Russian migrants in their new "homeland".

3 A homeland, according to Felicita Medved, can be described as a human condition, something that can be grasped emotionally rather than intellectually, - as an aspect of life, reflecting and interpreting the totality of life. 'Homeland' can mean a place or a region, but also territory and landscape, to which the migrant relates emotionally rather than politically or geographically ${ }^{4}$. One aspect of the homeland is linked to the concept of fatherland (or motherland). In the Middle Ages to die for one's fatherland was to die for an idea rather than for a territory. With the emergence of the modern nation state, a new principle of territory was introduced and we see the congruence between land and people and a strong relationship between blood and soil ${ }^{5}$. However, as Roger Just eloquently shows, for diaspora, blood and soil do not always coincide ${ }^{6}$. National territory is not only about space but also about emotional commitment to the homeland.

Homeland representations differ from one case to the other. Avtar Brah argues for a distinction between 'feeling at home' and declaring a place as home and speaks of homeland as an everyday lived experience and homeland as a territorially and politically defined nation. It is quite possible to feel at home in a place and, yet, the experience of social exclusion may inhibit public proclamations of the place as home. "The concept of diaspora places the discourse of 'home' and 'dispersion' in creative tension, inscribing a homing desire while simultaneously critiquing discourses on fixed origins. » Not all diaspora inscribe homing desire through a wish to return to a place of 'origin'. "Processes of diasporic identity formation are exemplars par excellence of the claim that identity is always plural and in process $»^{7}$. As far as the ethnic Greeks in the FSU are concerned, by the time of perestroika most considered themselves to be Soviet citizens, however much they cherished their Greek origins and looked to Greece as their 'historical homeland's. A distinction should also be made between 'old' and 'new' homelands. However, as I will try to show, the metamorphosis is not always successful. Not all migrants succeed to make the host society into a 'new' homeland.

5 The concepts of migration and homeland can be explored as expressions of continuous tension between movement and stability. Stability reflects a basic human need for order and maintenance offamiliarity, anchoring the present and the future in the past and constructing an experiential and historical continuity. Movement, on the other hand, is associated with a quest for change, improvement of life conditions and thirst for new experiences, exploration and demonstration of courage. A journey, whether real or imaginary, is a movement that takes a person away from his or her regular settings to a confrontation with new places, experiences or ideas?.

Language is a major locus of acculturation, stress or homesickness. The need to change one's language touches not only on everyday life issues but also on self-identity and on internal representations of significant people - including close family members, friends, and other prominent figures who were part of the migrant's life while growing up $^{10}$. Some claim that only upon leaving home do individuals become aware of the significance of language loss. In this way, language loss resembles other experiences in life, when only after losing something do we become aware of its value. In leaving the homeland, where we are able to anticipate, translate gestures, read others' faces, tones 
and voices, we also depart from the device that provides us with the security which we rely on, unremittingly and unconsciously, at home ${ }^{11}$.

7 Today, most ethnic Greeks in the FSU are mainly Russian speakers. Some Pontic Greeks speak or understand a variety of the Pontic Greek dialect, Rom; others speak a Turkic dialect, Urum. The Mariupol Greeks have their own Mariupol Greek dialect and also a Tatar based dialect, Urum. Today these dialects are spoken mainly by elderly people from rural areas. Occasionally, younger people also have a passive knowledge of them. Evidence suggests that the urban environment, along with Soviet language policies, have in many cases been damaging for the preservation of the spoken dialect ${ }^{12}$. Usually it is only upon arrival in Greece (or Cyprus) that ethnic Greeks from the FSU come into contact with modern Greek. Today, modern Greek is again taught in schools in areas with large numbers of ethnic Greeks as well as in associations.

\section{The Greek context}

In Greece, the preservation and promotion of a unified national identity and culture has been a concern for successive Greek governments ever since the country's inception as a state in $1832^{13}$. According to the Greek constitution, Greek nationality is allocated to all members of the Greek nation (to génos 'Ellines), which includes by definition all members of the Greek diaspora that are ethnically Greek. Both citizens of the homeland and their homogeneís in other countries are presumed to belong to the same community, sharing a collective identity independently of any actual collective experience. In the language of Benedict Anderson, these diaspora belong to the "imagined community" that make up the nation ${ }^{14}$.

These considerations are reflected in Greece's migration/repatriation policies. Persons of Greek origin and descent, the homogeneis, may claim citizenship through special measures, irrespective of the time their ancestors lived in other countries. Immigrants of non-Greek origin, the allogeneís, are considered foreign (allodapoí) ${ }^{15}$. Greek repatriation policy with regard to the Pontic Greeks ${ }^{16}$ from the FSU is conceived as an extension of the Lausanne Treaty of 1923 on the compulsory exchange of populations between Greece and Turkey. In 1990 the right to "return" was extended to all ethnic Greeks in the $\mathrm{FSU}^{17}$, who upon justified proof or their origin, could apply for a palinnóstisi or "return visa" from the Greek diplomatic services in Moscow and later also in the other NIS. Those who "return" are called palinnostoúntes or "repatriates"18 and are helped to settle via special measures taken by the Greek state for their training and education, housing, health and child care as well as counselling. In comparison with other groups of migrants, they either have facilitated access to Greek citizenship or an identity card, which stands for a residence and work permit ${ }^{19}$.

10 The existence of an important and diachronic Greek diaspora has considerably influenced the orientation of nationality and citizenship policies to a jus sanguinis logic. However, the official recognition by the Greek state that the migrants "have Greek blood" does not automatically lead to an equal recognition by Greek society. For most of the local Greeks the core of Greekness goes along with a standard repertoire of specific cultural features that these Soviet migrants lack.

11 How is Greekness defined? Who is a Greek? Koletti's answer to this question at the opening of the Greek parliament in 1844 was clear enough in that it was enumerative : 
« a man who lives in Jannina, Salonica, Serres, Adrianople, Constantinople, etc., or in any land associated with Greek history or the Greek race». Taking into account the spread of Hellenic cultural elements, in particular Greek language and Orthodox Christianity, the geographical spread of such an area was very large indeed ${ }^{20}$. More recently, the concept of Greekness has been subject to many debates ${ }^{21}$. According to Roger Just, in popular understanding an essentialist concept of the ethnos has prevailed where emphasis is put on Greek blood and descent : " the Greeks of Greece and the ethnos as a whole, whatever their language, whatever their customs, whatever their location, and whatever their citizenship, are Greek because they have 'Greek blood' ». And although "the notion of blood is increasingly seen as metaphorical, the notion of descent is not $»^{22}$. Renée Hirschon in her famous book on the Asia Minor refugees in Piraeus also speaks of the mystery of Greekness. Here emphasis is put on the distinguished identity of the Asia Minor refugees and on differences of degree rather than kind in relation to the host society ${ }^{23}$.

The position of Greek language in Greek society is indeed of special significance as it has been one of the main factors in the efforts to bring together Greeks at home and in the diaspora and vast efforts have been invested in ensuring that everyone learned Greek. Gradually, the social atmosphere is changing. The last decade has witnessed some superficial institutional indications of multiculturalism which mainly stem from EU policies. For all immigrants, the current policy is that schoolchildren must learn Greek; there is no immigrants' minority language instruction ${ }^{24}$. Likewise, social and political pressures emphasizing language hegemony are strongly felt ${ }^{25}$. For example, the fact that many ethnic Greeks like other migrants from the FSU continue to speak Russian in public places even after a long period in Greece annoys many local Greeks ${ }^{26}$.

\section{The material}

In this paper, I will discuss three books written by ethnic Greeks who have come to Greece from the FSU: The Athenian Labyrinth by Olga Papandopoulou (2001); Omonia Square (Place de la Concorde) by Hristos Vournas (2002) and A Greek woman with a Russian soul by Valida Budakidu (2008) ${ }^{27}$. Additionally, I will briefly refer to the collection of short stories, Masque. Stories of migrants in Greece by Ilona Talantseva and Katerina Arabadzhi (2006) and the novel The Confession of a millionaire by Ilona Talantseva (2004).

In all books, the main protagonists are first generation migrants. The novels by Olga Papandopoulou and Hristos Vournas are written largely in line with the dominant discourse in Greek society and reproduce elements of the Greek nationalist ideology. The stories collected and published by Ilona Talantseva and Katerina Arabadzhi are representative of migrants' concrete experiences in Greece. Finally, the book by Valida Budakidu is written in retrospective manner and discusses such issues as instrumental change of ethnic identity and nostalgia for the Soviet past.

Four out of five authors mentioned above are ethnic Greeks who have migrated to Greece from the NIS (Russia, Georgia and Ukraine) in the early 1990s. Olga Papandopoulou is a philologist. Valida Budakidu is a medical doctor who has published several books on migrant destinies of her fellow countrymen. Ilona Talantseva is editor-in-chief of the weekly Athens-based Russian language newspaper (Afiny Ellas). Katerina Arabadzhi is a journalist who works for the same journal. All are freelance 
journalists. Hristos Vournas is the only male author. His background is not clear. It is possible that he is a "returning" ethnic Greek who has arrived in Greece earlier.

The books by Olga Papandopoulou, Hristos Vournas and Ilona Talantseva/Katerina Arabadzhi have been published in Athens, Greece. The book by Hristos Vournas has been published by a Greek publishing house (Diogenis) while the three others have been published by the Athens-based Russian language newspapers Afinskii Kurier and Afiny Ellas. The book by Valida Budakidu has been published in St. Petersburg, Russia by a respected Russian publishing house that is well known for its scientific literature (Aleteïya). For this particular study, these books were chosen because the views expressed in them seemed to be representative of the actual situation of ethnic Greek and other migrants in Greece. On the hand, this genre of literature is not yet extensive in Greece, and these books were all that I could find.

The plot in The Athenian Labyrinth begins in Novorossiysk in Soviet Russia and takes us to Athens where the main action takes place. The hero of the story, Ljuba (Love) is a philologist of Greek origin from Novorossiysk who falls in love with a Greek navy officer, Nikos, and comes to Greece upon Nikos' request to be with her beloved. The love story with Nikos does not last long. Nikos belongs to an old Greek aristocratic family and is engaged to a girl of his family's choice. Pregnant with Niko's child, Ljuba has to face the struggle for survival alone. In the middle of difficulties, there are also moments of hope and joy.

Valida Budakidu's book, A Greek Woman with a Russian Soul is an autobiographical essay set in the first person. The hero of the story is an adult woman and mother of a young child who reflects on her life and on her identity. She is a doctor of Greek origin from Georgia who lives in Thessaloniki (Northern Greece). The book is full of irony and sarcasm. It is a commentary on life in Greece which is passing, according to the sequence of events, from an insider's to an outsider's point of view.

Finally, Omonia Square tells the story of an ordinary young Russian woman, Marina, from Moscow, who leaves behind a Russian man called Volodia and comes to Greece in pursuit of economic prosperity. The title of the book is very symbolic. These days, Omonia square (Place de la Concorde) in central Athens is a hub for recently-arrived migrants, drug dealers and prostitutes.

\section{Migrants' stories}

In all three stories, the heroes are women with strong will. Ljuba and Marina are also portrayed as beautiful and attractive women. In terms of ethnic belonging, Ljuba and Valida are ethnic Greeks, whereas Marina is Russian. However, all three are mainly portrayed as Russian-speaking ex-Soviet nationals. The reasons for migration are not explained exclusively by push and pull factors of the sending and receiving states: personal factors also intervene. Ljuba wanted to leave herfamiliar settings and face the challenge of the global world. The romance with Nikos merely served as an impetus to migration. In Valida's case, it appears that she left because everybody was leaving. The author tells us that after finishing school in Georgia she moved to Russia, and when she came back, almost all her friends had "become" Jewish and had left for Israel. Marina mainly wanted to pursue her personal dream and become "rich". Whatever the case, the departure signifies a breaking point : an individual feels or perceives that he or she 
must leave the area of origin. Whether or not this is part of a conscious decision, it is already a mental migration.

\section{Experiences of migration and settlement}

21 In the new homeland, our heroes struggle with daily problems and attempt to overcome the difficulties of adjustment. They have all experienced professional deskilling, betrayal, humiliation and dishonesty. We see the importance of connections and recommendations in finding work. We learn that only certain niches are open to non-EU/-EFTA nationals without papers, according to citizenship. In the case of women from the FSU, there is a choice between working in houses (cleaning, taking care of older people), working in a taverna (casual restaurant) or a dance bar. «Here we are a cheap labour force for wealthy Greeks ", Ljuba says. The authors also emphasize the psychological insecurity that the migrants face. With time, acquisition of legal status opens up new possibilities. After cleaning houses and working in a taverna, Ljuba becomes the secretary of an influential Greek businessman. Valida who was trained as a doctor in her home country also starts cleaning houses when she arrives in Greece. Later, she finds work as a cleaner in a medical office, then she becomes assistant to a doctor, and in the end, she opens her own doctor's surgery. Marina does all kinds of jobs that are open to migrants without papers: she sells things at open air markets, works in bars, cleans houses and offices and also works in the agricultural sector. Eventually, she decides to go to Cyprus and look for work with a Russian businessman ${ }^{28}$. There she manages to "make her dream come true" and earns a fair amount of money. Intermittently, she also returns to Moscow.

Individually and collectively, migrants seek acceptance in a new country, both from the host society and also from other ethnic groups. Marina, who is an ethnic Russian, is continuously told to search for her happiness in Russia. In Greece, she feels that she is treated like an object. Although Ljuba and Valida are ethnic Greeks, they too are mainly perceived as Russians. Valida tells us that in the first house where she worked, she was called "Rosida" (Russian) although she was perceived as a "non-Russian" in the Soviet Union. Ljuba's case is perhaps the most interesting. She is portrayed as the model immigrant. She works hard and quickly adopts the patterns of communication that are required in order to gain the acceptance of her new environment. She is prompt and polite and always ready to honour her hosts. Individually she is accepted and even liked. Nevertheless, on other occasions her citizenship is clearly a barrier. In the houses of her Greek boyfriends, her citizenship and old home country do not inspire confidence and are disapproved of. In another situation, she is dismissed from her job because of her citizenship. The association of her old homeland with the Russian mafia, networks of organized crime and Russian security services workagainst her ${ }^{29}$.

\section{Ascription, self-ascription and the politics of difference}

The perception of ethnic Greeks from the FSU in Greek society depends on the context. Although most refer to themselves as Ellines (Greeks) or Pontioi (Pontics), for the Greek state, the ethnic Greeks from the FSU are Ellines Pontioi (Greek Pontics), which is a label of national identity. However, in the media and in everyday speech, it is the term Rossopontioi (Russian Pontics) - a regional and national ascription marking their foreignness - which prevails. Faced with the often contradictory symbolic ascription of 
multiple identities, ethnic Greeks from the FSU confront formidable obstacles as they struggle to integrate into Greek society ${ }^{30}$. On the local labour market, their situation remains fragile. Among those who have finished university, only a small minority, approximately 10 per cent, work at their level of qualification ${ }^{31}$. Moreover, their culture brought from the FSU makes them different in the eyes of Greeks of Greece. It is this difference, along with their socially inferior status, that minorizes them and produces relations of subordination ${ }^{32}$. Social inequality is thus culturalized and naturalized. And as the book written by Valida Budakidu shows, professional integration alone does not automatically lead to cultural integration or public recognition. According to Irina Romanova, who has studied the Pontic Greeks in Cyprus, the hegemonic discourse of Greekness in their host societies does not provide the migrants with "discursive space" for being "different Greeks" and at the same time equally Greek. In the unofficial hierarchy of Greekness ${ }^{33}$, the migrants must either accept a status of "lesser Greek" or choose to resist and create their own version of what being a Greek might mean ${ }^{34}$.

As far as migrants of non-Greek origin, e.g. the Russians, are concerned, for the Greek state and society they are aliens ${ }^{35}$. As the book Omonia Square shows, although Marina quickly finds her economic independence, and later marries a Greek man with some wealth and status, in Greek society, she nevertheless remains an alien.

In all the novels that we have considered here, there is also a short reference to other groups, especially Albanians and Bulgarians, but also to ethnic Greeks and Russians who have arrived from the Soviet Union - in the 1930s and 1960s, thus inscribing Russian and Soviet migration to Greece into the longue durée $e^{36}$. An ethnic or a national group's strength is partially the status it can derive from its old homeland and from its earlier presence in the host country. For historical and geopolitical reasons, the representations of Russia in Greece are mainly positive ${ }^{37}$. On the other hand, there is also competition among different groups.For historical and political reasons, in Greece, the Albanians and the Bulgarians are perceived as the most controversial groups ${ }^{38}$. It is interesting that these are the groups that are referred to in our novels. Donald Horowitz explains this kind of dichotomization by the economy of antipathy. It is dangerous to have too many enemies and therefore more efficient to concentrate on the main problem ${ }^{39}$.

This leads us to other questions: Who are "we" and who are "they"? How is otherness defined? And what are the limits of otherness? Generally speaking, ethnic identity can be defined as a feeling of belonging and continuity in being, resulting from an aspect of self-ascription and/or ascription by others, to a group of people who claim both common ancestry and a common cultural tradition ${ }^{40}$. It can take its drive and pattern from an interplay of oppositions with outsiders, but mostly combines this source of differentiation with an internal source of identification ${ }^{41}$. According to Stuart Hall, cultural identity is a matter of 'becoming' as well as of 'being'. It belongs to the future as much as to the past. It is not something which already exists, transcending place, time, history and culture. Cultural identities come from somewhere, have histories. But, like everything which is historical, they undergo constant transformation. Far from being externally fixed in some essentialized past, they are subject to the continuous 'play' of history, culture and power ${ }^{42}$.

In the novels that we have discussed here, Ljuba has one Russian-speaking friend, an older woman called Maria, who is an ethnic Russian. Marina tells us that the only place where she feels happy in Greece is her friend Olimpia's house in Menidi. Olimpia is an 
ethnic Greek whereas Menidi is a municipality "at the edge of Athens" 43 , where Pontic Greeks from the FSU started settling in the late 1960s. Today, out of a population of approximately 75000 inhabitants, the Pontic Greeks from the FSU constitute 25 to 30 per cent ${ }^{44}$. In Greek public consciousness, Menidi is represented as an ill-famed place, inhabited by marginalized "Rossopontics" and Roma and characterized by high levels of unemployment and trafficking of drugs.

On the one hand, migrants find solidarity and compassion among members of their homeland; on the other, they are also involved in unpleasant, even violent, situations that are caused by their former countrymen. Both Ljuba and Marina are beaten up by Russians who are involved in trafficking of drugs and women. Both also have problems with the KGB and later with the Russian security services. It is interesting to note that the "bad guys" in the novels written by ethnic Greeks from the FSU in Greece are Russians. Especially in the earlier stories, (ethnic) Russians were frequently portrayed as drug dealers, junkies and prostitutes. Russian women were shown to be hard and selfish. This is very pronounced in the books written by Hristos Vournas (2002), Ilona Talantseva (2004) and Ilona Talantseva/Katerina Arabadzhi (2006). As far as the ethnic Greeks are concerned, they are mainly portrayed as sympathetic characters who are trying to reconstruct their lives in the context of their new host society. The portrayal of native Greeks varies fromself-interest, calculation, respect and distinction to humour, generosity, compassion and affection. Whatever the case, usually there is always a dividing line, a distinction between the groups, between us and them, that is, on the one hand, between the native Greeks and the ethnic Greeks, and on the other, between the ethnic Greeks and the "Russians".

The authors of the books clearly show that Greece is a society which categorizes migrants on the basis of their supposed ethnic origin. Actually, upon arrival in Greece, the situation of migrants from the FSU is often quite similar. Irrespective of their ethnicity, they share a common Soviet past and culture and arrive in a country which de facto is foreign to them, in most cases without knowledge of the language. As is well shown in the novels, in this early stage they often have informal relations between them, which help to overcome initial difficulties in the new host society. However, over time, their paths tend to diverge. This can be explained by the different policies of the Greek state with regard to migrants according to their supposed ethnic origin, but also by different life projects at the outset and as a consequence, by different survival and integration strategies in the context of the new host society ${ }^{45}$. Here it is interesting to note that in some other countries, e.g. in Finland and in Israel, that also have received large numbers of migrants from the FSU since perestroika, in scientific literature and in the media, it is quite common to refer to the Russian speaking migrants as one group without always categorizing the migrants according to their supposed ethnic origin ${ }^{46}$.

\section{Representations of home(s) and homeland(s)}

Much literature on the individual's relation to home and homeland tends to focus on the homeland as the object of one's longing. In Homer's Odyssey, a migratory epic, the homeward journey and arrival at home basically becomes an end in itself. Nostos survives through nostalgia, or a sense of melancholy and homesickness when a depressed body and mind long for home during an absence from it. While the stories of Ljuba and Valida are essentially about migration, they are reminders of other and 
earlier stories of migration and nomadism in space and time. Thus, reclaiming the past is likened to the creation of fictitious, invisible and imaginary homelands.

As far as Ljuba and Valida and the "returning" ethnic Greeks from the FSU are concerned, we could say that they chose to "return" to an "imaginary homeland" or to an "imagined community" according to the term used by Benedict Anderson ${ }^{47}$. We are told that Ljuba's mother is an ethnic Greek from Batumi (Georgia), and that her family had been deported to Kyrgyzstan as part of the Stalinist deportations in the aftermath of the Second World War. More recently, the family moved to Novorossiysk in the Russian Caucasus. Ljuba's mother maintained correspondence with relatives in Greece for many years. Ljuba was familiar with the family history and knew some Greek from home. Valida tells us that she left Georgia because everybody was leaving. Departure is thus defined not as an individual project, but as an adaptation to new collective attitudes and schemas. In other stories, ethnic Greeks simply state that they came to Greece "because they were Greek"

As far as the perception of the new social environment is concerned, we can see that Ljuba is very excited about everything. Before coming to Greece she had never been outside her republic of origin. After several years in Greece, she continues to relate affectively to her new physical and human environment. She is a recent migrant and works in the houses of wealthy Greeks, whereas a significant part of the action takes place in beautiful settings and in tourist attractions. Valida's case is different. She seems to be acquainted with the history and the geography of her new homeland, and gives information about people and situations that she has experienced. However, she does not seem to have any profound attachment to places or persons. The reader is confronted with a sense of loneliness and melancholy. The hero of the story has much to tell but nobody to talk to. Here the plot is mainly set in a municipality of Thessaloniki inhabited by a large number of "returning" ethnic Greeks and in the countryside. In other migrant stories, I am thinking especially of the collection of short stories edited by Ilona Talantseva and Katerina Arabadzhi (2006), there are many examples of emotional attachment to Greece, whether to a particular city or to the whole country. Usually it is based on positive experiences and is linked to romance, love, friendship or to the opportunity of doing academic studies in the new country. The ethnic origin of the heroes is not an issue.

Attitudes to the old and the new homeland are often related to the individual's age at the time of emigration and to the time spent in the new homeland. They are also related to economic, political and cultural transformations in the old homeland. The way that the migrant chooses to express and live out attachment to old and new homelands is revealing of the contradictions and the tensions with which he or she is confronted. In our novels, the old homeland is not discussed in depth. In Ljuba's case, it is the starting point of her story and a point of reference. When her life situation becomes difficult, Ljuba sends her child to Russia to stay with her mother. Valida reflects on her life in the Soviet Union (in Georgia and in Russia) and is a little nostalgic about the past; however, the everyday lived experience is set in Greece. The book by Hristos Vournas is an exception. In Marina's case there is a constant va-et-vient between Moscow, Greece and Cyprus. The author writes about the structural changes in Russia and we can see how the lives of Marina's family and friends "back home" change during a relatively short period of time. 
As Eric Hobsbawm notes, there is an ambiguity or contradiction between home and homeland. Home - dom, doma in Russian - is primarily private. But in a wider sense, home - rodina in Russian - is primarily public, a collective definition, and as such, a social construction. Valida recalls her hometown and her school, how it was to belong to an ethnic minority group in the Soviet Union. We are told that in her hometown the Greeks were the elite. She does not even mention her family home. On the other hand, while an individual can establish a home, and even a better home than the one he/she left behind, only community allows for the understanding of a homeland ${ }^{49}$. However, in the new homeland, a profound sense of "existential insideness" is not always possible as the membership in the new community depends not only on the migrant's will, but also on the acceptance of the "natives". On the other hand, not all migrants are willing or able to fit it.

As is well known, "integration is a two-way street" ${ }^{50}$. If migrants are willing to adapt to local ways, natives must also be willing to treat them like locals. However, if a society is hostile or indifferent, then with the best will in the world, migrants will not be able to fit in. As a consequence, if a society initially rejects migrants who want to fit in, they and their children may become resentful or even hostile, even if the society subsequently becomes more welcoming. Likewise, if migrants do not want or are unable to fit in, the society may become hostile to them, making them and their children feel excluded. In both cases, the society may conclude from their resentment that the migrants have no desire to fit in and so attack and exclude them, causing a new cycle of resentment and misunderstanding ${ }^{51}$. In our novels, Greece is portrayed as a country where it is not easy to be a migrant and become accepted. In parallel, the way other groups, especially Albanians, are portrayed tends to reproduce the negative stereotypes prevalent in Greek society.

In relation to the host society, in Greece our heroes are portrayed as outsiders, as "marginal" people who are not quite part of the society in which they live. They are also portrayed as strong characters. Life teaches them how to stand up and fight for their rights. It also teaches them how to respect themselves and to inspire self-respect from others. Age and family situation also matter. Upon arrival in Greece, Ljuba and Marina are young independent women, whereas Valida is already married. Ljuba has consciously broken with her past, which facilitates her integration process in the new homeland. However, she is still a recent migrant and is struggling to find her place in the new social environment. Valida is an older migrant whose life follows set patterns. She is professionally integrated and mother to a young child. Finally, as far as Marina is concerned, emotionally she never broke with her homeland and her own past in Russia. The fact that she marries and has a child with a wealthy Greek man in Greece does not change her perception of things. Her life and dreams are oriented towards her old love in Moscow.

When it comes to cultural understanding and intimacy in the new homeland, the role played by the Russian language cannot be undermined. In some cases, the Church can also provide an anchorage. Although the father and the godfather of her child are native Greeks, Ljuba baptizes her child in the Russian Orthodox Church. On some occasions, appointments for work are fixed in the church yard. When everything goes wrong, Marina finds her way to the Russian Orthodox Church where she meets other Russian speakers, old migrants who came to Greece in the 1930s. Through the Church she finds again faith and hope, which soon turn into passion for life. Valida does not 
speak of religion. However, the role of the Russian language in her life is primordial. The people she calls her own ("svoi" in Russian) are migrants from the former Soviet Union. She can recognize them in the street even when they are of thethird generation.

Generally speaking, too little time has passed since the arrival of the new Soviet/postSoviet diaspora in Greece, to speak of important identity changes, of broken, fractured or silenced identities as Svetlana Prozhogina does pertaining to the North African diaspora in France ${ }^{52}$. We see a little of this in Marina's story in the novel by Hristos Vournas. After her marriage to a wealthy Greek man, Marina dyes her hair black. There is also a change in her personality. She becomes like "everybody". Nobody pays attention to her anymore. Her joy for life disappears and she has a profound identity crisis. Becoming a mother, in the first place she must think of her child. However, she is still in love with Volodia. Towards the end of the novel, Marina says that she cannot ignore herself, her history and her homeland; she cannot forget who she is and become somebody else. When her child is two years old, Marina decides to take a holiday and go to Moscow to find Volodia.

As Harald Runblom notes, homeland relations transcend an individual's lifetime. Thus for a comprehensive study, a multigenerational perspective is necessary. Migrants' homeland relations also provide a base for long-term relationships between countries. Migrants and their descendants serve as mediators of culture, and migration bolsters cultural exchange, economic cooperation, and in some cases even severe conflicts between states ${ }^{53}$.

\section{Conclusion}

In Greece, fiction written by ethnic Greeks from the FSU who arrived in Greece after perestroika started appearing in the 1990s. In this paper, I have referred mainly to three novels : The Athenian Labyrinth by Olga Papandopoulou (2001), A Greek Woman with a Russian Soul by Valida Budakidu (2008) and Omonia square by Hristos Vournas (2002). They are migration stories that discuss the fate of ethnic Greek and Russian migrants in their new homeland.

41 The novels by Olga Papandopoulou and Hristos Vournas are written in line with the dominant discourse in Greek society and reproduce elements of the Greek nationalist ideology. The stories collected and published by Ilona Talantseva and Katerina Arabadzhi are representative of migrants' concrete experiences in Greece. All in all, the voices represented in these books are typical of the heterogeneity and complexity of the situations of the recent Soviet/post-Soviet diaspora in Greece. In the end it appears that the common Soviet and Russian cultural heritage, the common cultural features and the sense of intimacy that they produce are as important and decisive for these migrants as their ethnic or national identity. 


\section{NOTES}

1. This has been done by the local poets and activists of the Greek associations set up during perestroika. In the publications that started appearing in the 1980s the authors often speak of their Greek roots and the traditions that were maintained in their Greek village. They also tell us about their Soviet upbringing in the school and in the army. The "national revival", the setting up of Greek cultural associations, the celebration of Greek holidays and the first journey to Greece are described with excitement and emotion.

2. Since the mid-1980s approximately 200000 ethnic Greeks from the FSU have migrated to Greece. Ministry for Macedonia and Thrace, I tavtotita ton palinnostounton omogenon apo tin proin ESSD [The identity of the returning ethnic Greeks from the FSU], 2000 ; Interview with Mr. M. Eleftheriadis, President of the Pan-Hellenic Union for Greek refugees who have arrived in Greece from Russia since 1957, Athens, April 2004. The total number of migrants who have arrived in Greece from the FSU since perestroika is estimated at 300 000. Interview with Mr. K. Karamarkos, Counsellor to the General Secretary for Greeks Abroad, Ministry for Foreign Affairs of Greece, Athens, May 2001.

3. In Greece, the Russian language newspapers were never very numerous. Over the years, some have disappeared, some have merged, some have split into two and new ones have been founded. Today there are at least three Athens-based Russian language newspapers : Omonia, Afinskii Kurier, Afiny Ellas. Additionally, some Pontic associations have / have had their own Russian language / bilingual newsletters. In content, the Russian language newspapers are similar and include world news, Greek news, news from the newly independent states (NIS), aspects of Pontic history, migrations letters and advertisements of all kinds.

4. Medved (F.), "The Concept of Homeland», in Runblom (Harald), ed., Migrants and the Homeland. Images, Symbols and Realities, Uppsala : Uppsala University (Uppsala Multiethnic Papers 44), 2000.

5. Runblom (Harald), "Introduction: Homeland as imagination and reality ", in Runblom (Harald), ed., op.cit., pp. 9-30, 11.

6. Just (Roger), « Triumph of the Ethnos », in Tonkin (Elizabeth), MacDonald (Maryon), Chapman (Malcolm), eds., History and Ethnicity, London / New York : Routledge, 1989.

7. Brah (Avtar), Cartographies of Diaspora. Contesting Identities, London / New York: Routledge, 1996, pp. 192, 197.

8. Voutira (Eftihia A.), « Post-Soviet Diaspora Politics : The case of the Soviet Greeks », Journal of Modern Greek Studies, 24 (2), 2006, pp. 398-399.

9. Medved (F.), art.cit., p. 92.

10. Grinberg (Lesn), Grinberg (Rebeca), Psychoanalytic Perspectives of Migration and Exile, New Haven: Yale University Press, 1989; Tannenbaum (Michal), «Back and Forth: Immigrants' stories of migration and return », International Migration, 45 (5), 2007, p. 149.

11. Tannenbaum (Michal), art.cit.

12. Chassiotis (I.), ed., Oi Ellines tis Rosias kai tis Sovietikis Enosis : Metoikesies kai ektopismoi, organosi kai ideologia [The Greeks in Russia and the Soviet Union: Transfers and displacements, organization and ideology], Athens : University Studio Press, 1997 ; Voutira (Eftihia A.), art.cit.; Kaurinkoski (Kira), « Les Grecs de Mariupol (Ukraine). Réflexions sur une identité en diaspora », Revue Européenne des Migrations Internationales, 19 (1), 2003 ; Kaurinkoski (Kika), « Migration from Ukraine to Greece since perestroika: Reflections on the migration process and on collective identities ", Migrance (Special Issue on Greece),31, 2008.

13. The Treaty of London of 1832 establishing Greece was signed by Great Britain, France and Russia. 
14. Voutira (Eftihia A.), art.cit.

15. Baldwin-Edwards (Martin), «Semi-Reluctant Hosts: Southern Europe's Ambivalent Response to Immigration », Studi Emigrazione, (145), 2002 ; Kaurinkoski (Kika), « Migration from Ukraine to Greece since perestroika » (art.cit.).

16. The Pontic Greeks made up two thirds of the ethnic Greeks in the FSU. They are descendants of migrants from the Greek communities of Pontos, the Turkish coast of the Black Sea (Pont Euxin) who left this region for the Russian Empire (and later Soviet Union) between the end of the eighteenth and the beginning of the $20^{\text {th }}$ centuries, as a consequence of Russo-Turkic wars or attracted by advantages accorded to the foreign settlers.

17. The ethnic Greeks in the FSU can be divided into four subgroups: the Pontic Greeks, the Mariupol Greeks, the descendants of Greek settlers from continental Greece and the Aegean and Ionian islands who arrived in Southern Russia in the eighteenth and nineteenth centuries and the political refugees of the Greek Civil War (1944-1949). However, with regard to the political refugees different repatriation policies were applied. On the Greeks in Russia and the Soviet Union, e.g., Chassiotis (I.), ed.,op.cit.;Ivanova (Yu.), Greki Rossii i Ukrainy [The Greeks in Russia and Ukraine], St Petersburg : Russian Academy of Sciences / Aleteïya, 2004. On the Pontic Greeks, e.g., Bruneau (Michel), éd., Les Grecs pontiques. Diaspora, identités, territoires, Paris : CNRS, 1998 ; Journal of Refugee Studies (4), 1991 ; Notaras (Andreas), Les Grecs pontiques de la région de Krasnodar (Fédération de Russie). Transformations de l'organisation sociale et de l'identité ethnique au XXe siècle, Paris : EHESS (thèse de Doctorat), 2005. On the Mariupol Greeks, e.g., Kaurinkoski (Kika), Les Grecs dans le Donbass. Analyse des identités collectives dans deux villages d'Ukraine orientale, Université de Provence (Aix-Marseille I), novembre 1997 (thèse de Doctorat); Kaurinkoski (Kika), « Les Grecs de Mariupol (Ukraine) » (art.cit.).

18. The term palinnóstisi meaning "repatriation" or "return to one's homeland" has been criticized by migrants, politicians and policy-makers for being controversial and inexact as the ethnic Greeks in the FSU were not born in Greece, and only in a few exceptional cases was there an organized repatriation procedure by the Greek state. However, for official use, the terms "repatriation" and "repatriate" were chosen to reflect the ideological, voluntary and individual character of the migration process to Greece. E.g. Argyros (A.),

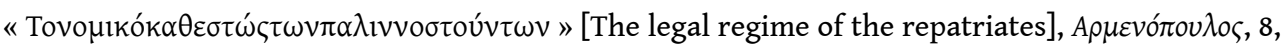
2001 ; Kaurinkoski (Kika), « Migration from Ukraine to Greece since perestroika » (art.cit.).

Personally, I prefer to speak of "ethnic" or "privileged migration", as suggested by some other scholars for similar migration movements, e.g., Münz (Rainer), ohliger (Rainer), Diasporas and Ethnic Migrants, Germany, Israel and Post-Soviet Successor States in Comparative Perspective, London: Frank Cass, 2003; Yelenevskaya (M.), Fialkova (L.), Russkaya ulitsa $v$ yevreïskoï strane. Issledovaniye folklora emigrantov 1990- $h v$ Izraile [ARussianStreetinaJewishCountry. Research on the folklore of the emigrants of the 1990s in Israel], Moscow :RussianAcademyofSciences, 2005 ; Voutira (Eftihia A.), art.cit.;Kaurinkoski (Kika), «Le 'retour' des Grecs de l'ex-Union soviétique : politiques d'accueil et stratégies des migrants dans l'agglomération athénienne », inBerthomière (William), Chivallon (Christine), éds., Les diasporas dans le monde contemporain, Paris : MSHA-Karthala, 2006 ; Čapo-Zmegač (Jasna), Strangers either way, The lives of Croatian refugees in their new home, New York / Oxford : Berghahn Books, 2007.

19. Between 1990 and 2009, three periods can be distinguished according to the legislation and repatriation policy in force. With Law 2790/2000, in force currently, the responsibility for the resettlement and naturalization process has been moved from the Ministry of Foreign Affairs to the Ministry of Interior, Public Administration and Decentralization and the number of documents required to submit a demand has been reduced. Meanwhile, a Commission rehearsal has been added, checking Greek consciousness. Moreover, whereas previously, ethnic Greek migrants simply arrived in the country and registered with their municipality, with the new law, for the first time, there is an actual naturalization process. For those who do not want to lose the 
citizenship of their country of origin, as Ukraine and also some other NIS do not recognize double citizenship, there is a possibility of acquiring an identity card. However, this card, which stands for a residence and work permit is not equal to citizenship and does not give the right to vote. E.g. Argyros (A.), art.cit.; Kaurinkoski (Kika), «Le 'retour' des Grecs de l'ex-Union soviétique " (art.cit.); Kaurinkoski (Kika), «Migration from Ukraine to Greece since perestroika » (art.cit.).

20. Just (Roger), art. cit., pp. 79-80.

21. E.g. Tsaousis (D. G.), ed., Ellinismos kai ellinikotita [Hellenism and Greekness], Athens : Estia, 2001 ( $4^{\text {th }}$ edition).

22. Just (Roger), art.cit.

23. Hirschon (Renee), Heirs of the Greek Catastrophe. The social life of Asia Minor Refugees in Piraeus, New York / Oxford : Berghahn Books, 1998 (original in 1989), p. 246.

24. Oral communication by Martin Baldwin-Edwards, Mediterranean Migration Observatory, www.mmo.gr; also www.imepo.gr and the Greek Ministry of Education.

25. On Greek education policy and practice in Greece, e.g., Damanakis (M.), I ekpaidevsi ton palinnostounton kai Allodapon Mathiton stin Ellada [Education of ethnic Greek and alien pupils in Greece], Athens : Gutenberg, 2002.

26. Interviews with migrants and with the native Greek population in the greater Athens area, 2001-2006.

27. Papandopoulo (0.), Afinskii Labyrint [The Athenian Labyrinth], Athens: Afinskiï Kurier [Russian language weekly Athens Courier], 2001 ; Vournas (H.), Ploshad' Omonia [Omonia Square], Athens: Diogenis, 2002; Talantseva (I.), Ispoved millionera [The Confession of a Millionaire], Athens, 2004 ; Talantseva (I.), Arabadzhi (K.), Maska. Istorii emigrantov v Gretsii [Masque. Stories of Migrants in Greece], Athens: Afiny Ellas [Russian language weekly Athens Hellas], 2006; Budakidu (V.), Grecanka russkaya dushoï [A Greek Woman with a Russian Soul], St Petersburg: Aleteïya, 2008.

28. Especially in the early 1990s, Cyprus was an important host country for Russian off-shore companies. Today, there is still an important Russian business community in Cyprus.

29. On the activities of the KGB in Greece, e.g. Malyshev (V.), Greceskie taïny i sekrety [Greek Mysteries and Secrets], Athens: Scorpion International, [s.d.]. The author is a former Soviet correspondent for the Russian news agency TASS who currently lives and writes in Greece. He is the founder of the Athens-based Russian language newspaper Afinskii Kurier.

30. Karakasidou (Anastasia), "Review Essay: Migrant Encounters with Power in Greece", Journal of Modern Greek Studies, 20 (1), 2002.

31. Kaurinkoski (Kika), « Le 'retour' des Grecs de l'ex-Union soviétique » (art.cit.).

32. Guillaumin (Colette), L'idéologie raciste. Genèse et langage actuel, Paris : Mouton, 2002.

33. Triandafyllidou (Anna), Veikou (Mariangela), «Hierarchies of Greekness : Ethnic and National Identity Considerations in Greek Immigration Policy ", Ethnicities, 2 (2), 2002 ; Christopoulos (D.), «Peripeteies tis ellinikis ithageneias : poios (den) ehei ta prosonta na einai Ellinas » [Adventures of Greek citizenship. Who does (not) have the qualifications to be Greek ?], Thesis, (87), 2004.

34. Romanova (I.), «'Other Greeks' : Discursive construction of ethnicity by Greek migrants from the former Soviet Union in Cyprus ", Unpublished Conference Paper, Critical Approaches across Disciplines (CADAAD, 2008), 10-12/07/08, University of Hertfordshire, UK.

35. Baldwin-Edwards (Martin), art.cit.

36. On earlier Russian and Soviet migration to Greece, e.g. Divani (Lena), « The Russian Refugees in Greece, a First Attempt to Register », Balkan Studies, 35 (1), 1994 ; Zapantis (Andrew L.), GreekSoviet Relations 1917-1941, New York : Columbia University Press, 1982. 
37. Zapantis (Andrew L.), op.cit; Chassiotis (I.), Episkopisi tis istorias tis neoellinikis diasporas [Study of the History of the Greek Diaspora], Thessaloniki : Vanias, 1993 ; Chassiotis (I.), ed., op. cit.

38. The Albanians constitute the largest immigrant population in Greece representing approximately 65 per cent of the total migrant population. Until recently, in the media and popular speech they were usually portrayed as the scapegoat for all evil. The Bulgarians, although far less numerous, are often perceived as the historical enemy. E.g., Koliopoulos (John S.), Veremis (Thanos), Greece, the Modern Sequel. From 1831 to the Present, London: Hurst, 2002 ; Sintès (Pierre), Les Albanais en Grèce, mobilités, réseaux et territoires, Université de Nice SophiaAntipolis (thèse de Doctorat) ; Hatziprokopiou (Panos), « Albanian immigrants in Thessaloniki, Greece : processes of economic and social incorporation ", Journal of Ethnic and Migration Studies, 29 (6), 2003 ; Baldwin-Edwards (Martin), Statistical Data on Immigrants in Greece : An Analytic Study of Available Data and Recommendations for Conformity with European Union Standards. A Study Conducted for IMEPO [Migration Policy Institute], Greece, by MMO, UEHR, Panteion University, 2004.

39. Horowitz (Donald L.), Ethnic Groups in Conflict, London : University of California Press, 1985.

40. Hutnik (Nimmi), Ethnic Minority Identity. A Social Psychological Perspective, Oxford: Clarendon Press, 1991.

41. Roosens (Eugeen), "The Primordial Nature of Origins in Migrant Ethnicity ", in Vermeulen (Hans), Govers (Cora), eds., The Anthropology of Ethnicity. Beyond 'Ethnic Groups and Boundaries', Amsterdam : Het Spinhuis, 2000, pp. 84-85.

42. Hall (Stuart), "Cultural Identity and Diaspora », in Braziel (Jana Evans), Mannur (Anita), eds., Theorizing Diaspora. A Reader, Malden (Mass.) : Blackwell, 2003, p. 236.

43. There is a powerful movie on the Pontic Greeks from the FSU in Menidi called Apo tin akri tis polis [From the edge of town] by K. Giannaris.

44. On the Pontic Greeks in Menidi, e.g. Kaurinkoski (Kika), Nommer et classer dans les Balkans: Les Grecs de l'ex-Union soviétique dans l'agglomération athénienne, Non-published thesis presented to the Academy of Inscriptions and Arts, Ecole française d'Athènes, 2005 ; Vergeti (M.), Omogeneis apo tin proin Sovietiki Enosi 1985-1995 [Ethnic Greeks from the FSU 1985-1995], Thessaloniki : Kyriakidi, 1998.

45. On the policies and practices of categorization in Greece and in the Balkans, e.g. de Rapper (Gilles), Sintès (Pierre), eds., Nommer et classer dans les Balkans, Athènes: Ecole française d'Athènes, 2008. Also Kaurinkoski (Kika), «Migration from Ukraine to Greece since perestroika » (art.cit.), p. 78.

46. E.g. Yelenevskaya (M.), Fialkova (L.), op.cit. ; Jasinskaja-Lahti (Inga), Liebkind (Karmela), "Exploration of the Ethnic Identity of Russian-Speaking Immigrant Adolescents in Finland ", Journal of Cross-Cultural Psychology, 30 (4), 1999.

47. Anderson (Benedict), L'imaginaire national. Réflexions sur l'origine et l'essor du nationalisme, Paris : La Découverte, 2002.

48. According to the Soviet passport system, which was in force from 1932 until the dissolution of the Soviet Union, the nationality (nacionalnost) of each person was stated in his or her passport. For the Soviet administration, all ethnic Greeks indistinctive of their regional or linguistic origins or identities were labeled as "Greki"[Greeks]. At the age of sixteen, children born from mixed marriages had the right to choose between the nationalities of the parents. In the second part of the twentieth century, many chose Russian, Ukrainian or Georgian according to their republic of residence. Usually these choices were motivated by thoughts of comfort and expectations of social benefits. In terms of career advancement, it was more advantageous to belong to a "people with a recognized territory". Nevertheless, by those who chose to stay "Greek", the latter were often seen as "traitors of the group". E.g. Kaurinkoski (Kika), Les Grecs dans le Donbass (op.cit.) ; Kaurinkoski (Kika), « Les Grecs de Mariupol (Ukraine)» (art.cit.); Notaras (A.), op. cit. 
49. Hobsbawm (Eric), «Introduction », Social Research, 58 (1), 1991.

50. On integration, e.g., Lucassen (Leo), Feldman (David), Oltmer (Jochen), eds., Paths of Integration. Migrants in Western Europe (1880-2004), Amsterdam : Amsterdam University Press, 2006 ; Inglessi (Chrissi), Lyberaki (Antigone), Vermeulen (Hans), Wijngaarden (Gert Jan van), eds., Immigration and Integration in Northern versus Southern Europe, Athens : The Netherlands Institute at Athens, 2004 ; Pélissier (Michel), Paecht (Arthur), éds., Les modèles d'intégration en question. Enjeux et perspectives, Paris : IRIS / PUF, 2004 ; Legrain (Philippe), Immigrants, Your Country Needs Them, London : Abacus, 2009.

51. Legrain (Philippe), op. cit., pp. 257-258.

52. Prozhogina (S.), «Literatura frankoyazychnyh magribintsev o drame severoafrikanskoï diaspory" [The literature of Francophone Maghrebinians about the Drama of the North African Diaspora], Diasporas (Moscow), 4, 2005.

53. Runblom (Harald), ed., op.cit.

\section{ABSTRACTS}

The first novels and short stories written by ethnic Greeks from the former Soviet Union (FSU) who arrived in Greece after perestroika were published in the 1990s in weekly Athens-based Russian language newspapers which started appearing at that time. In this paper, I refer mainly to three novels: The Athenian Labyrinth by Olga Papandopoulou (2001), A Greek Woman with a Russian Soul by Valida Budakidu (2008) and Omonia Square by Hristos Vournas (2002). They are migration stories which discuss the fate of ethnic Greek and Russian migrants from the FSU in their new homeland. The voices presented in these novels are representative of the heterogeneity and complexity of situations of the recent Soviet/post-Soviet diaspora in Greece. In the end, it appears that the common Soviet and Russian cultural heritage, the common cultural features and the sense of intimacy that they produce are equally decisive for these migrants as their ethnic or national identity.

Les premiers romans écrits par les Grecs soviétiques venus en Grèce après la perestroïka furent publiés dans les années 1990 dans les journaux russophones hebdomadaires qui commençaient à paraître à cette période. Dans cet article, je me réfère principalement à trois romans:Le labyrinthe athénien d'olga Papandopoulou (2001), Une femme grecque avec un âme russe de Valida Boudakidou (2008) et la Place Omonia de Hristos Vournas (2002). Il s'agit des histoires de migration qui traitent du destin des migrants soviétiques dans leur nouveau pays d'accueil. La pluralité des voix décrites dans ces romans est représentative de l'hétérogénéité et de la complexité des situations des diasporas Soviétiques/post-Soviétiques en Grèce. Enfin, il paraît que l'héritage culturel commun russe et soviétique ainsi que les caractéristiques culturels et le sens de l'intimité qu'ils produisent sont aussi importants pour ces migrants que leur identité ethnique ou nationale.

\section{INDEX}

Geographical index: Grèce, Russie, U.R.S.S.

Mots-clés: Fiction, identité, migrations, représentations 


\section{AUTHOR}

\section{KIRA KAURINKOSKI}

The author is an anthropologist and a research associate of Institut d'ethnologie méditerranéenne européenne et comparative (UMR 6591, CNRS \& Universités d'Aix-Marseille I and III) and the French School of Athens

karrinko@otenet.gr, kaurinkoski@yahoo.fr 